\title{
Developing a genetic evaluation system for milk traits in Russian black and white dairy cattle
}

\author{
Andrei A. Kudinov ${ }^{1,2}$, Jarmo Juga², Esa A. Mäntysaari ${ }^{3}$, Ismo Strandén ${ }^{3}$, Ekaterina I. Saksa ${ }^{1}$, \\ Michael G. Smaragdov ${ }^{1}$ and Pekka Uimari² \\ ${ }^{1}$ Russian Research Institute of Farm Animal Genetics and Breeding - Branch of the L.K. Ernst Federal Science Center for Animal \\ Husbandry, Saint-Petersburg, Russia \\ ${ }^{2}$ University of Helsinki, Fl-00014 Helsinki, Finland \\ ${ }^{3}$ Natural Resources Institute Finland (Luke), Fl-31600 Jokioinen, Finland \\ e-mail: andrei.kudinov@helsinki.fi
}

\begin{abstract}
Mixed linear models have been applied for predicting breeding values of dairy cattle in most of the developed countries since the 1980s. However, the Russian Federation is still using the old contemporary comparison method. The objective of our study was to develop a best linear unbiased prediction (BLUP) for an animal model of breeding values for the Leningrad region. We tested both a first-lactation model (FLM) and a multi-lactation repeatability model (MLM). The data included milk records of 206114 cows from 49 herds. Estimated heritabilities from FLM were $0.24,0.20$, and 0.20 for milk, protein, and fat yields, respectively, and $0.18,0.19$, and 0.20 from MLM. Repeatabilities were 0.34 for milk yield and 0.31 for both fat and protein yields. Genetic trends were similar for both models (FLM vs MLM): 59 vs $56 \mathrm{~kg}$ year $^{-1}$ for milk, 1.90 vs $1.84 \mathrm{~kg} \mathrm{year}^{-1} \mathrm{for}$ fat, and 1.67 vs $1.62 \mathrm{~kg}_{\text {year }}{ }^{-1}$ for protein yield during 2000-2016. Based on the difference between the genetic trends in FLM and MLM, the applied BLUP method passed the validation method I by Interbull.
\end{abstract}

Key words: genomic evaluation, dairy cattle, BLUP, REML, breeding value

\section{Introduction}

Holstein is the most popular dairy breed in the world. Holsteins are also very popular in the Russian Federation, with a population of over 360000 dairy cows. Only the Russian Black and White (RBW) breed is more popular, with over 1.6 million cows. The RBW breed was created by crossbreeding native Russian breeds with imported Dutch bulls in various parts of Russia since the 1820s. In 1925, RBW was defined as a target milk cattle breed by the Soviet government, and many Ost-Frisian bulls were therefore imported from Germany, Estonia, Lithuania, and the Netherlands to various regions of Russia. In 1959, the Ministry of Agriculture registered RBW as a breed and began purebred breeding. The decision was based on breed characteristics, which were high milk yield, good meat quality, and adaptability to various climate conditions across the country (Arzumanyan et al. 1973). The breeding goal has changed over the years, and farmers currently prioritize milk yield and milk content traits over other traits. During the last decades, imported Holstein bulls have been used to improve the production and type traits of RBW cattle. Semen, young calves and heifers have been imported from the Netherlands, Germany, the Nordic Countries, USA, and Canada. Current Russian dairy herds are a mixture of RBW and Holstein cattle, with various breed ratios across regions.

The Leningrad region is a district in the northwestern European part of Russia, bordering Finland and Estonia. The region has the highest average milk yield per cow in Russia (8243 kg in 2016) (Yearbook 2017). Herd size in the Leningrad region varies from 800 up to 4000 animals, including cows, heifers, calves, and young bulls. In the Leningrad region, official milk recording is performed once a month and includes measurements of milk yield, and fat and protein contents. A technician takes milk samples for the fat and protein content measurements. The samples are processed either by farmers using their own milk analyzers or by an independent laboratory. The laboratory can send the results directly to the central database or back to the farmer, depending on the farmer's choice. All data are stored and processed by the regional data center Plinor LLC (http://www.plinor.spb.ru/). Milk volume data can be entered into the central database by a technician or directly through the automatic milking systems (AMS). In addition to milk recording, each cow is evaluated twice during its lifetime (during the first and third lactations) for body condition, udder composition, and leg condition. The fertility traits, health traits, somatic cell counts, and veterinary services are also recorded for certain herds. All cows are artificially inseminated in the Leningrad region, and information concerning the service sire is stored in the database. 
The current prediction of breeding values for dairy bulls in the Russian Federation is based on contemporary comparison (Bulls' evaluation instruction 1980). This method is old and inefficient, dating back to 1972 (Norman 2013). Evaluation and ranking of bulls is based on comparing the milk yield and fat content of a bull's daughters to the production ability of their contemporaries in the same or in similar herds (Kudinov et al. 2017). Thus, estimated breeding values (EBV) are not available for cows or young bulls, and systematic environmental effects are not considered in a proper way. Several attempts have been made to apply the best linear unbiased prediction (BLUP) (Henderson 1973) methods for bull and cow evaluation in the Russian Research Institute of Farm Animal Genetics and Breeding, RRIFAGB in the 1980s (Shkirando 1986, Ignashkina and Kuznetsov 1988, Myakoshina 1992), but BLUP-based evaluation has not been applied at the industry level. Modernizing the breeding value evaluation system in Russia is therefore extremely essential.

The objective of our study was to develop the first animal model BLUP of breeding value estimation for RBW dairy cattle in the Leningrad region. We also discuss pitfalls in the current recording system that affect the evaluations, and provide recommendations for improvements.

\section{Material and methods}

\section{Milk recording and pedigree data}

All data were obtained from milk recording data base in Plinor (StPetersburg, Russia). The data included 49 herds with purebred RBW and Holstein cattle. All herds were from the Leningrad region and could be considered largescale production herds with 300 to 500 (10 herds), 500 to 1000 ( 33 herds), and >1000 milking cows (five herds). Milk yield, fat and protein content were measured once a month during the lactation period (approx. 10 measurements), and were available for cows born between 2000 and 2013. Based on monthly milk yield, and fat and protein percentages, fat and protein yields were calculated by Plinor and were available for our study. Lactation number, calving date, and dry-off day were also available.

According to Russian federal legislation (State order №379 2010) the milk, fat, and protein yields of a cow in lactation for at least 240 days can be treated as a 305-day record without correcting for the short lactation interval. To avoid possible bias in the records due to short lactations, all short-interval records from the cows with no subsequent lactation were excluded from the analysis because we did not have enough information available to extend these records into 305-day records. In addition, records that deviated three standard deviations from the mean were excluded from the analyses. Only records up to five lactations were considered. The total number of records before data editing was 552807 from 206114 cows. After data editing, 320633 records remained for the analysis. Table 1 presents the number of records within each lactation and the number of records excluded from the analysis due to short lactation.

Table 1. The number of records in the data by lactation

\begin{tabular}{ccc}
\hline Lactation & Number of cows with a full 305-day record & $\begin{array}{c}\text { Number of cows with a short lactation record } \\
(240-305 \text { days })\end{array}$ \\
\hline 1 & 141868 & 11180 \\
2 & 91269 & 9736 \\
3 & 51239 & 8020 \\
4 & 25298 & 4882 \\
5 & 10959 & 2597 \\
Total & 320633 & 36415 \\
\hline
\end{tabular}

${ }^{1}$ These records were not included in the final data

Currently, the ID of an animal is a combination of a short herd ID and the name of the animal. Thus, the same name and number combination can occur on different farms for different animals. To avoid this during the pedigree and phenotypic data editing, we used unique identification numbers generated by Selex ${ }^{\circledR}$ (http://www. plinor.spb.ru/). These were 13-digit-long IDs constituting sex as the first digit, herd code as the next seven digits, and an animal's personal number as the last five digits. 
A. A. Kudinov et al. (2018) 27: 85-95

Pedigree data were available for animals born between 1969 and 2016. For each animal, the pedigree data included ID, birth year, and IDs of the sire and dam. The total number of animals in the pedigree was 452622 (Table 2). The pedigree's oldest animals were historical bulls from the 1960s. The most complete part of the pedigree began from 1990. Prior to the variance component and breeding value estimation, the animal IDs were renumbered, and animals not contributing to the variance component estimation were pruned using the RelaX2 program (Stranden and Vuori 2006). The final pedigree data included 2341 sires with progeny and the average number of daughters per sire was $158, \mathrm{SD}=470$.

Table 2. Number of animals $(N)$ in the pedigree by birth year

\begin{tabular}{|c|c|c|c|c|c|c|c|c|c|}
\hline Birth year & $\mathrm{N}$ & Birth year & $\mathrm{N}$ & Birth year & $\mathrm{N}$ & Birth year & $\mathrm{N}$ & Birth year & $\mathrm{N}$ \\
\hline 1962 & 1 & 1974 & 217 & 1985 & 3934 & 1996 & 11540 & 2007 & 16352 \\
\hline 1963 & 1 & 1975 & 181 & 1986 & 5298 & 1997 & 11583 & 2008 & 17486 \\
\hline 1964 & 4 & 1976 & 193 & 1987 & 6748 & 1998 & 12659 & 2009 & 17719 \\
\hline 1965 & 4 & 1977 & 182 & 1988 & 8326 & 1999 & 13515 & 2010 & 19270 \\
\hline 1966 & 3 & 1978 & 310 & 1989 & 9741 & 2000 & 14246 & 2011 & 20504 \\
\hline 1968 & 7 & 1979 & 287 & 1990 & 10924 & 2001 & 14140 & 2012 & 21597 \\
\hline 1969 & 6 & 1980 & 700 & 1991 & 10943 & 2002 & 14673 & 2013 & 21991 \\
\hline 1970 & 39 & 1981 & 851 & 1992 & 10883 & 2003 & 14730 & 2014 & 20382 \\
\hline 1971 & 34 & 1982 & 1383 & 1993 & 10496 & 2004 & 15238 & 2015 & 21004 \\
\hline 1972 & 135 & 1983 & 2081 & 1994 & 10112 & 2005 & 16234 & 2016 & 5215 \\
\hline 1973 & 119 & 1984 & 2842 & 1995 & 10579 & 2006 & 15315 & Unknown & 9665 \\
\hline
\end{tabular}

\section{Estimation of variance components and breeding values}

A single trait animal model with either first lactation records (first-lactation model, FLM) or a repeatability model for up to five lactation records (multi-lactation model, MLM) from all data was used in the variance component and breeding value estimations. For each trait, the following mixed linear model was applied:

$$
y=X b+Z_{1} a+Z_{2} p+e
$$

where $y$ is a vector of yield records (either 305-day milk, fat, or protein yield), $b$ is the vector of the fixed effects, $a \sim N\left(0, A \sigma^{2}{ }_{a}\right)$ and $p \sim N\left(0, I \sigma_{p}^{2}\right)$ are vectors of random animal and permanent environmental effects, respectively, $X$ is a design matrix, which relates fixed effects to records, $Z_{1}$ and $Z_{2}$ are design matrices relating random effects to records, and $e^{\sim N}\left(0, I \sigma_{e}^{2}\right)$ is the vector of the residual effects. Matrix $A$ is the relationship matrix, $I$ is an identity matrix, and $\sigma_{a^{\prime}}^{2} \sigma_{p^{\prime}}^{2}$ and $\sigma^{2}$ correspond to additive genetic, permanent environmental, and residual variances, respectively. The permanent environmental effect was not included in the FLM.

The herd-year-season effect (HYS) and a combined age of calving and days open effect (DOAC) were the fixed effects. The HYS included 2603 classes in total, with a range from 10 to 300 observations per HYS class. Age of calving and days open included 22 and 28 classes, respectively. The DOAC effect was formed by merging the number of days open (DO, Table 3 ) and the age of calving (AC, Table 4) classes within the same lactation number.

Many initial DOAC classes had a small number of observations, which reduces the power of estimating these effects. Several small classes were therefore combined. The largest DOAC class, with 11174 observations, was a combination of class 4 in DO (first lactation) and class 3 in AC (first lactation). The smallest DOAC classes were from the fourth and fifth lactations, and these classes were combined in later analysis. 
Table 3. Number of records in various days open classes and lactations

\begin{tabular}{|c|c|c|c|}
\hline Lactation & Class & $\begin{array}{l}\text { Length of days open } \\
\text { (days) }\end{array}$ & Number of records \\
\hline \multirow[t]{8}{*}{1} & 1 & Missing records & 2776 \\
\hline & 2 & $20-59$ & 10510 \\
\hline & 3 & $60-92$ & 23718 \\
\hline & 4 & $93-188$ & 57447 \\
\hline & 5 & 189-231 & 14736 \\
\hline & 6 & $232-282$ & 12133 \\
\hline & 7 & $283-379$ & 12117 \\
\hline & 8 & $380-580$ & 8431 \\
\hline \multirow[t]{8}{*}{2} & 1 & Missing records & 2052 \\
\hline & 2 & $20-51$ & 3628 \\
\hline & 3 & $52-82$ & 11811 \\
\hline & 4 & 83-116 & 16439 \\
\hline & 5 & $117-157$ & 16748 \\
\hline & 6 & $158-235$ & 20477 \\
\hline & 7 & $236-313$ & 10952 \\
\hline & 8 & $314-535$ & 9162 \\
\hline \multirow[t]{7}{*}{3} & 1 & Missing records & 1314 \\
\hline & 2 & $20-48$ & 1477 \\
\hline & 3 & $49-82$ & 6873 \\
\hline & 4 & 83-159 & 19419 \\
\hline & 5 & $160-236$ & 11129 \\
\hline & 6 & $237-314$ & 6016 \\
\hline & 7 & $315-520$ & 5011 \\
\hline \multirow[t]{5}{*}{$4-5$} & 1 & Missing records & 1072 \\
\hline & 2 & $20-58$ & 1896 \\
\hline & 3 & 59-119 & 10892 \\
\hline & 4 & $120-215$ & 12939 \\
\hline & 5 & $216-500$ & 9458 \\
\hline
\end{tabular}

The same model, pedigree and phenotypic data were used in the variance component and breeding value estimation. However, phantom parent groups were included in the breeding value estimation analysis, because a large number of imported animals, especially sires, did not have parental information. We defined six main phantom groups: sires of Russian sires, dams of Russian sires, sires of Russian cows, dams of Russian cows, sires of foreign animals, and dams of foreign animals. The main phantom groups were further divided into subgroups according to the birth year of the animal. The total number of phantom groups was 218 . We treated the phantom parent groups operationally as random effects in the analysis by adding a constant of 0.33 to the diagonals of the group effect equations in the mixed model equations (Schaeffer 1994).

Variance components were estimated by restricted maximum likelihood (REML) (Patterson and Thompson 1971) using the Al-REML method in the DMU program package (Madsen and Jensen 2013). Breeding values were estimated using the MiX99 program package (MiX99 Development Team 2015). Reliabilities were calculated by the Misztal and Wiggans approximation method (Misztal and Wiggans 1988) using the apax99 program of the MiX99 program package. We validated the breeding values using Interbull Method I (Boichard et al. 1995), where the estimated breeding values from the FLM are compared to estimated breeding values from the MLM. 


\begin{tabular}{|c|c|c|c|}
\hline Lactation & Class & Age in months & Number of records \\
\hline \multirow[t]{8}{*}{1} & 1 & $19-23$ & 15156 \\
\hline & 2 & 24 & 21230 \\
\hline & 3 & 25 & 27412 \\
\hline & 4 & 26 & 24003 \\
\hline & 5 & 27 & 17782 \\
\hline & 6 & $28-29$ & 19819 \\
\hline & 7 & $30-32$ & 10842 \\
\hline & 8 & $33-60$ & 5624 \\
\hline \multirow[t]{5}{*}{2} & 1 & $27-36$ & 13973 \\
\hline & 2 & $36-38$ & 19560 \\
\hline & 3 & $39-40$ & 18795 \\
\hline & 4 & $41-43$ & 19881 \\
\hline & 5 & $44-81$ & 19060 \\
\hline \multirow[t]{3}{*}{3} & 1 & $39-50$ & 12883 \\
\hline & 2 & $51-54$ & 16572 \\
\hline & 3 & 55-90 & 21784 \\
\hline \multirow[t]{4}{*}{4} & 1 & $51-62$ & 5066 \\
\hline & 2 & $63-67$ & 8716 \\
\hline & 3 & $68-100$ & 11516 \\
\hline & 1 & $63-70$ & 3186 \\
\hline \multirow[t]{2}{*}{5} & 2 & $77-82$ & 3952 \\
\hline & 3 & 83-105 & 3821 \\
\hline
\end{tabular}

\section{Results}

\section{Phenotypic means}

The average milk yield of the cows in the final data varied from $7644 \mathrm{~kg}$ to $8165 \mathrm{~kg}$ depending on lactation; the highest yields were obtained for second and third lactation cows and the lowest for first-lactation cows (Table 5). The corresponding descriptive statistics for fat and protein yields are given in Tables 6 and 7. The highest fat yield was observed for third-lactation cows and the lowest for first-lactation cows, varying from $296 \mathrm{~kg}$ to $317 \mathrm{~kg}$. The highest protein yield was produced during the second lactation $(271 \mathrm{~kg})$ and the lowest during the fifth lactation $(252 \mathrm{~kg})$.

Table 5. Number of observations (N), mean, standard deviation (SD), minimum value (Min), and maximum value (Max) of the 305-d milk yield (kg)

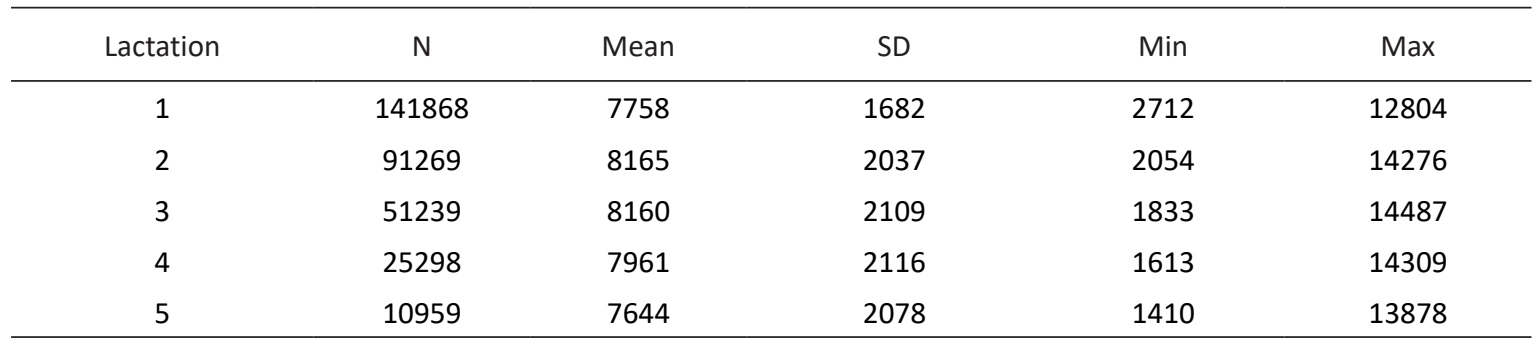


Table 6. Number of observations (N), mean, standard deviation (SD), minimum value (Min), and maximum value (Max) of the fat yield $(\mathrm{kg})$

\begin{tabular}{|c|c|c|c|c|c|}
\hline 1 & 141756 & 296 & 63 & 106 & 486 \\
\hline 3 & 50827 & 317 & 79 & 80 & 554 \\
\hline 4 & 25088 & 311 & 80 & 71 & 551 \\
\hline
\end{tabular}

Table 7. Number of observations (N), mean (Mean), standard deviation (SD), minimum value (Min), and maximum value (Max) of the protein yield $(\mathrm{kg})$

\begin{tabular}{|c|c|c|c|c|c|}
\hline Lactation & $\mathrm{N}$ & Mean & SD & Min & Max \\
\hline 1 & 124485 & 256 & 49 & 108 & 402 \\
\hline 3 & 45463 & 270 & 62 & 84 & 456 \\
\hline 4 & 22680 & 263 & 62 & 77 & 449 \\
\hline
\end{tabular}

\section{Variance components}

Table 8 presents estimate variance components for milk, fat, and protein yields. Using the MLM, the estimated heritability of milk yield was 0.18 . Heritabilities of protein and fat yields were 0.19 and 0.17 , respectively. Repeatabilities were 0.34 for milk yield and 0.31 for both fat and protein yields. Heritabilities from the FLM for fat and protein were both 0.20 and the estimated heritability for milk yield was 0.24 . Standard errors were small for all heritability estimates (Table 8).

Table 8. Estimates of genetic $\left(\sigma^{2}\right)$, permanent environment $\left(\sigma_{p}^{2}\right)$, and residual $\left(\sigma_{e}^{2}\right)$ variance components, heritability $\left(h^{2}\right)($ standard error), and repeatability ( $r$ ) for milk yield traits

\begin{tabular}{ccccccc}
\hline Model & Trait & $\sigma^{2}{ }_{a}$ & $\sigma^{2}{ }_{p}$ & $\sigma^{2}{ }_{e}$ & $h^{2}$ & $R$ \\
\hline \multirow{2}{*}{ FLM } & Milk & 301465 & NA & 936884 & $0.24(0.008)$ & NA \\
& Fat & 328 & NA & 1353 & $0.20(0.007)$ & NA \\
& Protein & 223 & NA & 915 & $0.20(0.008)$ & NA \\
& Milk & 313916 & 281706 & 1138386 & $0.18(0.004)$ & 0.34 \\
& Fat & 412 & 324 & 1630 & $0.17(0.005)$ & 0.31 \\
& Protein & 295 & 210 & 1074 & $0.19(0.004)$ & 0.31 \\
\hline
\end{tabular}

\section{Estimated breeding values}

Figure 1 shows the genetic trends of milk yield using both FLM and MLM for cows born between 2000 and 2016. The EBVs were centered using the average EBV of cows born in 2009-2011.

The average genetic trend in milk yield was $59 \mathrm{~kg}_{\text {year }}{ }^{-1}$ using FLM. A slightly smaller trend ( $56 \mathrm{~kg} \mathrm{year}^{-1}$ ) was observed with MLM. The genetic trends from FLM and MLM were quite similar up to year 2010. After that, MLM gave a slower genetic trend than FLM. The maximum genetic trend for FLM was $83 \mathrm{~kg}_{\text {year }}{ }^{-1}$ for years 2009 and 2010 , and the minimum was $20 \mathrm{~kg}_{\text {year }}{ }^{-1}$ for years 2014-2016. The trend difference between FLM and MLM was $3 \mathrm{~kg}$, which is smaller than the Interbull criterion of $0.02 * \sigma_{\mathrm{a}}(=0.02 * \sqrt{ } 313916=11.2 \mathrm{~kg})$. 


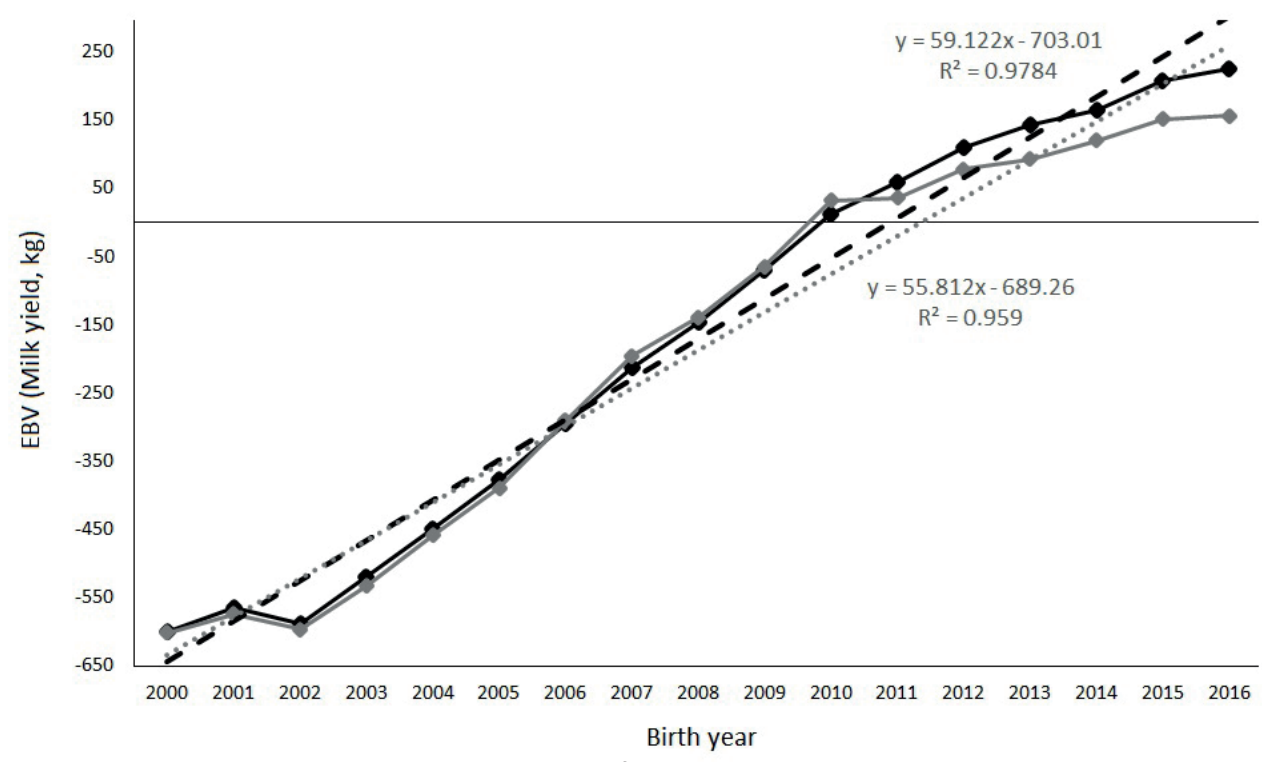

Fig. 1. Obtained genetic trend in milk yield for cows and corresponding regression lines with equation showing annual response using a single-lactation model (black lines) or a multilactation model (gray lines).

Genetic trends for fat and protein yields are presented in Figures 2 and 3. The trends were nearly identical for FLM and MLM: $1.90 \mathrm{~kg}_{\text {year }}{ }^{-1}$ and $1.84 \mathrm{~kg}_{\text {year }}{ }^{-1}$ for fat yield and $1.67 \mathrm{~kg}_{\text {year }}{ }^{-1}$ and $1.62 \mathrm{~kg}$ year ${ }^{-1}$ for protein yield. The maximum genetic trend in fat yield was obtained between 2006 and $2008\left(3.3 \mathrm{~kg} \mathrm{year}^{-1}\right)$ and the minimum trend during 2009 and $2010\left(-0.8 \mathrm{~kg} \mathrm{year}^{-1}\right)$. Genetic progress for fat yield was flat from 2012 to 2016 . For protein yield, the maximum trend was observed for 2006 and 2007 ( $3.1 \mathrm{~kg}$ year $\left.{ }^{-1}\right)$, and a negative genetic trend of $-0.2 \mathrm{~kg}$ year ${ }^{-1}$ was observed between 2009 and 2010. The trend was flat in 2012-2016. The difference between the FLM and MLM trends was $0.06 \mathrm{~kg}$ for fat yield and $0.05 \mathrm{~kg}$ for protein yield. Both differences are smaller than the $\mathrm{In}$ terbull criterion of $0.02 * \sigma_{\mathrm{a}}$.

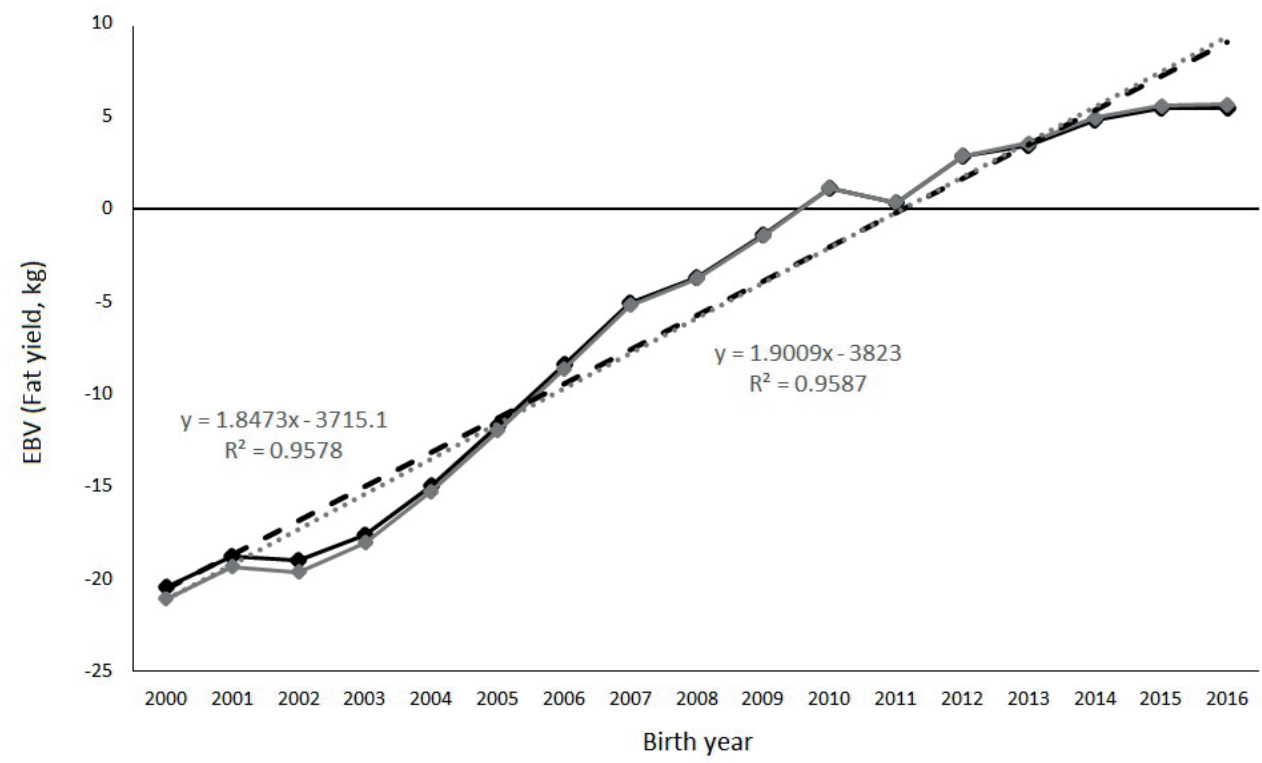

Fig. 2. Obtained genetic trend in fat yield for cows and corresponding regression lines with equation showing annual response using a single-lactation model (black lines) or a multilactation model (gray lines) 


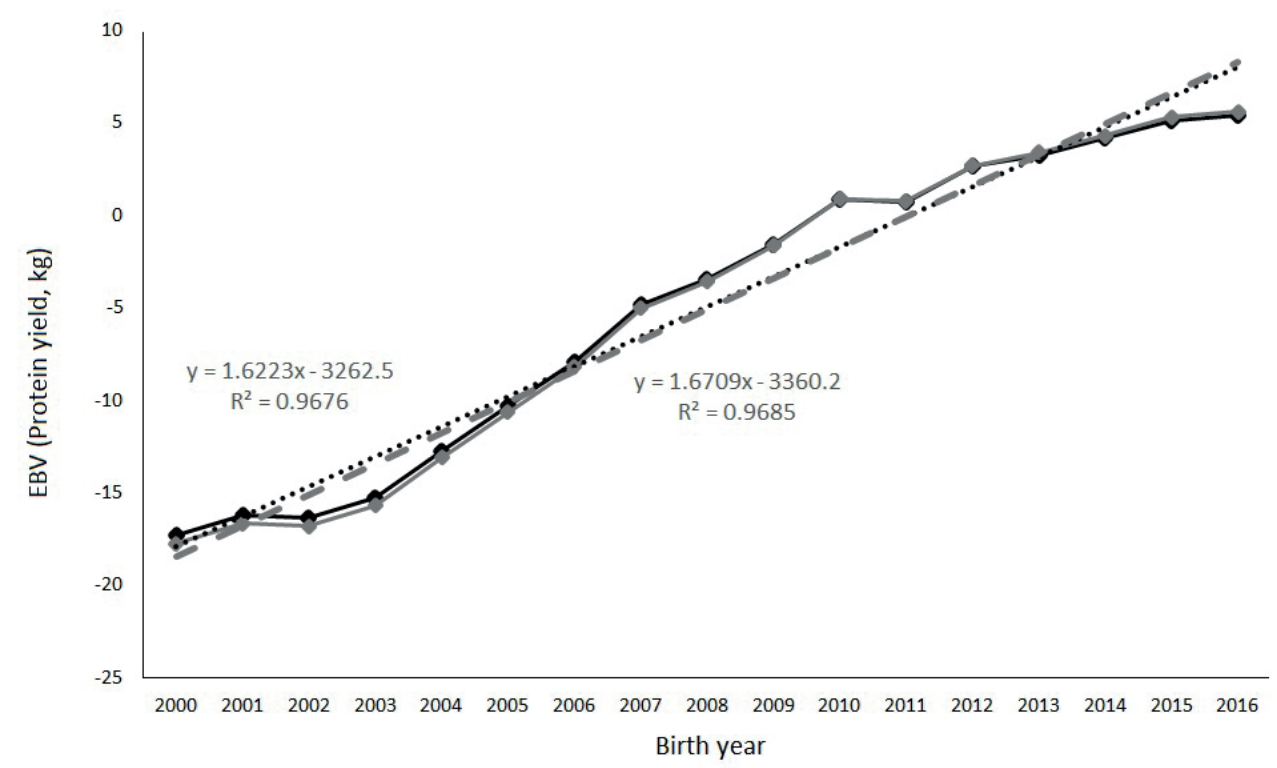

Fig. 3. Obtained genetic trend in protein yield for cows and corresponding regression lines with equation showing annual response using a single-lactation model (black lines) or a multi-lactation model (gray lines)

Solutions for the phantom groups are presented in Figure 4 for the groups 'sires-of-sires' and 'dams-of-sires', based on the birth year of the sires. Based on our results, the quality (measured as the EBV of milk yield) of imported sires improved during 2000 (bulls born before 2008).

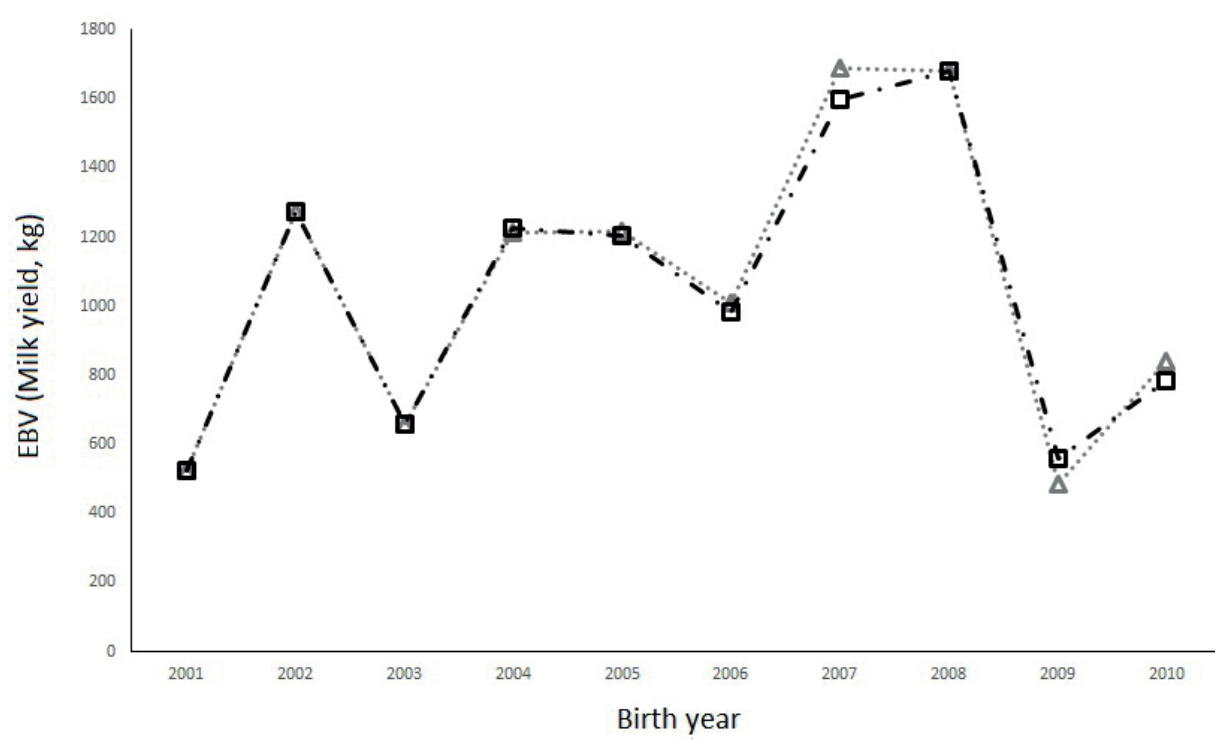

Fig. 4. Genetic trend of the phantom parent groups 'sires-of-sires' (gray triangle) and 'dams-of-sires' (black squares) of imported animals

The quality of imported bulls born in 2009 and 2010 is not as high as that of bulls born before 2009. This may be due to importation of bulls with genomic prediction of breeding values with lower accuracy than previously imported progeny tested bulls or due to semen pricing or marketing reasons.

\section{Reliabilities}

The average reliabilities of the EBVs for milk, fat, and protein yields in Russian and foreign bulls born in 1999-2009 and with more than 20 daughters was $70 \%$ and $61 \%$, respectively. The EBVs of cows born in 2000-2009 had an average reliability of 39\%. The average reliability of EBVs of those cows born in 2014-2016, which did not have their own records, was $20 \%$. The reliability of EBVs for non-proven bulls with a low number of progeny was $19 \%$. 


\section{Discussion}

The obtained heritabilities $(0.18-0.24)$ for the milk production traits were quite close to the parameter estimates on Tunisian Holsteins (Ben Zaabza et al. 2016), but still lower than those reported for other Holstein populations, e.g. the heritability estimates for milk production traits in the US (Carabano et al. 1989) and Kenyan (Ojango and Pollott 2001) Holstein population were around 0.3. Heritability and repeatability are population-specific, and depend on both genetic and non-genetic variances. Due to frequent importation of Al bulls and semen from Western countries, the genetic background of cows in the Leningrad region is likely very similar to those of the exporting countries. However, non-genetic variation cannot be controlled. Larger environmental variance in the Leningrad region compared to Western countries may be due to day-to-day variation in feeding and in other herd management systems. In addition, variation in milk recording, e.g. different analyzers and various ways of entering data into the central database, create additional noise in milk, fat, and protein yield records. Heritability is a population parameter and influenced by the estimate of the environmental variance, i.e. the goodness of the data and model. It also depends on the quality of the pedigree data. Some insight into $\mathrm{h}^{2}$ of lactation milk traits can be found in an old review by Maijala and Hanna (1974). Boldman and Freeman (1988) showed same influence of growing residual variance on heritability. Thus, the reason for the low heritabilities is more likely a large residual variance than a small additive genetic variance.

The overall genetic trends of cows for milk, protein, and fat yields are positive, but less progressive compared to countries from where the Holstein breed bulls have been imported from, e.g. Canada (https://www.cdn.ca/files_ ge_articles.php); the annual progress in 2004-2014 was $61.4 \mathrm{~kg}$ in the Leningrad region and $85.4 \mathrm{~kg}$ in Canada. The genetic progress in fat (1.84-1.90 kg year $\left.{ }^{-1}\right)$ and protein yields $\left(1.62-1.76 \mathrm{~kg} \mathrm{year}^{-1}\right)$ is less dynamic than in Canada (4.2 and $3.3 \mathrm{~kg}_{\text {year }}{ }^{-1}$, respectively). The high percentage of imported top sires is the most likely explanation for the positive genetic trend in the Leningrad region. The effect of domestic bull selection on genetic progress is probably small due to the inefficient estimation of the breeding values of bulls and the lack of breeding values of cows. Better on-farm management is also partly responsible for the improved (phenotypic) milk production.

The small observed over estimation of milk yield trend in the FLM model and no difference with fat and protein yield trends in comparison to the MLM model can be caused by model and data limitations. Model can be modified to reduce residual variance and account breed structure of population. For example, including Herd-Year $x$ lactation interaction could fix problems in the milk yield trend of MLM. Likewise, including heterosis in the model may be valuable because RBW cows in different herds have different ancestry proportions with HOL breed. In addition, $40 \%$ of the excluded records in the raw data were shorter than 240 days which may cause a bias in the genetic trend estimation.

The Russian Federation and the Leningrad region are not members of ICAR (The International Committee for Animal Recording). Thus, the devices used in milk recording are not necessarily approved by ICAR, and the recording practices do not necessarily follow ICAR guidelines. In addition, the old system of using non-automatic methods to measure milk and its contents can create quality problems in the data. Data quality could be improved by adopting ICAR guidelines and best practices in milk recording. Plinor has indicated readiness to receive data directly from milk laboratories or robots to the central database, but farmers do not generally use this opportunity. Because no governmental or other rules related to automatic data collection are implemented, farmers transfer milk results from the laboratory to the central database partly manually. This makes the data less reliable, as the opportunity to make mistakes exists during data input.

Problems may also arise in animal identification and pedigree records. The lack of a central national database or herd book for animal identification causes problems in pedigree quality and completeness. The number of imported sires is high. These animals usually have a short pedigree (reaching back by only five generations). Imported animals receive new ID numbers when entering the country. The Russian ID number is not ICAR-based, and farmers use short ID numbers. Plinor has solved this problem in the Leningrad region by creating internal unique ID numbers. Short pedigrees and the extensive use of imported bulls in the breeding scheme cause large phantom parent groups. This may have a negative effect on EBV reliabilities (Wolak and Reid 2017). Despite all these factors, our evaluation model was successfully used, and passed the validation method I by Interbull. 


\section{Conclusions}

Our paper presents the first BLUP estimates for breeding values of RBW cattle in the Leningrad region. An up-todate genetic evaluation system is a crucial step when moving towards genomic prediction. The practices developed in our study concerning data editing can be applied at the industry level to improve routine recording. The breeding value estimation model can also be improved by adapting a test-day model, instead of using 305-day records. Furthermore, pedigree quality can be improved by manually tracing bull pedigrees using international information sources. Reliable EBVs enhance the selection of more profitable cows and a successful breeding program. Rapid genetic improvement and accurate breeding value estimation should increase the number of local bull candidates for Al stations and aid in the exchange of genetic material between various regions of Russia.

\section{Acknowledgements}

Our study was funded by the FASO State Assignment № AAAA-A18-118021590138-1 and № AAAAA18-118021590134-3. We also thank the regional recording center Plinor LLC, Agriculture and Fishery Committee of the Leningrad region and the head of RRIFAGB, Kirill V. Plemyashov.

\section{References}

Arzumanyan, E.A., Markin, E.F. \& Ryabov, U.K. 1973. Ural Black and White cattle, Moscow, Kolos publish. 20 p. (in Russian).

Ben Zaabza, H., Ben Gara, A., Hammami, H., Amine Ferchichi, M. \& Rekik, B. 2016. Estimation of variance components of milk, fat, and protein yields of Tunisian Holstein dairy cattle using Bayesian and REML methods. Archives Animal Breeding 59: 243-248. https://doi.org/10.5194/aab-59-243-2016

Boichard, D., Bonaiti, B., Barbat, A. \& Mattalia, S. 1995. Three methods to validate the estimation of genetic trend for dairy cattle. Journal of Dairy Science 78: 431-437. https://doi.org/10.3168/jds.S0022-0302(95)76652-8

Boldman, K.G. \& Freeman, A.E. 1988. Estimates of Genetic and Environmental Variances of First and Later Lactations at Different Production Levels. Journal of Dairy Science 71: 81-82. https://doi.org/10.1016/S0022-0302(88)79982-8

Bulls evaluation instruction 1980. Instruction for the inspection and evaluation of bulls of dairy and meat milk breeds on the quality of offspring. Moscow, USSR Ministry of Agriculture, 1979.

Carabano, M. J., Van Vleck, L.D., Wiggans, G.R. \& Alenda, R. 1989. Estimation of Genetic Parameters for Milk and Fat Yields of Dairy Cattle in Spain and the United States. Journal of Dairy Science 72: 3013-3022. https://doi.org/10.3168/jds.S0022-0302(89)79454-6

Henderson, C.R. 1973. Sire evaluation and genetic trends. Journal of Animal Science 1973 (Issue Symposium). p. 10. https://doi. org/10.1093/ansci/1973

Ignashkina, A.A. \& Kuznetsov, V.M. 1988. Breeding value evaluation of bulls using MCC and BLUP methods. RRIFAGB Bulletin 101: 3-5. (in Russian).

Kudinov, A.A., Juga, J., Uimari, P., Mäntysaari, E.A., Strandén, I., Plemyashov, K.V., Saksa, E.I. \& Smaragdov, M.G. 2017. Upgrading Dairy Cattle Evaluation System in Russian Federation. Interbull Bulletin 51: 67-74.

Madsen, P. \& Jensen, J. 2013. A User's Guide to DMU. Version 6, release 5.2. University of Aarhus, Denmark.

Maijala, K. \& Hanna, M. 1974. Reliable phenotypic and genetic parameters in dairy cattle. Proceedings of the World Congress on Genetics Applied to Livestock Production, Volume 1, Madrid, Spain. p. 541-563.

Misztal, I. \& Wiggans, G. R. 1988. Approximation of prediction error variance in large-scale animal models. Journal of Dairy Science 71: 27-32. https://doi.org/10.1016/S0022-0302(88)79976-2

MiX99 Development Team 2015. MiX99: A software package for solving large mixed model equations. Release VIII/2015. Natural Resources Institute Finland (Luke). Jokioinen, Finland. http://www.luke.fi/mix99

Myakoshina, L.A., Klimez, N.V. \& Kuznetsov V.M. 1992. BLUP models choosing for bulls evaluation. RRIFAGB Bulletin 133: 12-15. (in Russian).

Norman, D. 2013. Contemporary comparison. In: Grosu, H., Schaeffer, L., Oltenacu, P.A., Norman, D. Powell, R. Kremer, V., Banos, G., Mrode, R., Carvalheira, J., Jamrozik, J., Draganescu, C. \& Lungu, S. (eds.). History of Genetic Evaluation Methods in Dairy Cattle. Bucharest, Romania: The Publishing House of the Romanian Academy. 334 p.

Ojango, J. \& Pollott, G. 2001. Genetics of milk yield and fertility traits in Holstein-Friesian cattle on large-scale Kenyan farms. Journal of Animal Science 79: 1742-1750. https://doi.org/10.2527/2001.7971742x

Patterson, H.D. \& Thompson, R. 1971. Recovery of inter-block information when block sizes are unequal. Biometrika 58: 545-554. https://doi.org/10.1093/biomet/58.3.545

Schaeffer, L.R. 1994. Multiple-country comparison of dairy sires. Journal of Dairy Science 77: 2671-2678. https://doi.org/10.3168/ jds.S0022-0302(94)77209-X

Shkirando, U.P. 1986. Increasing the effectiveness of evaluation of the genotype of dairy cattle using Breeding Value Indexes, list squares and BLUP. Dissertation. (in Russian). 
State order №379 2010. State order on the approval of the procedure and conditions for carrying out classification of dairy and dairy-beef cattle breeds. Moscow, Ministry of Agriculture, 2010. (in Russian).

Strandén, I. \& Vuori, K. 2006. RelaX2: pedigree analysis programme. In: Proceedings of the 8th World Congress on Genetics Applied to Livestock Production, Belo Horizonte, Minas Gerais, Brazil. p. 27-30.

Yearbook 2017. Yearbook of breeding work in dairy cattle of Russian Federation in 2016, Moscow, VNIIPlem, 2017. (in Russian).

Wolak, M.E. \& Reid, J.M. 2017. Accounting for genetic differences among unknown parents in microevolutionary studies: how to include genetic groups in quantitative genetic animal models. The Journal of Animal Ecology 86: 7-20. https://doi.org/10.1111/13652656.12597 